\title{
Microbial electrolytic disinfection process for highly efficient Escherichia coli inactivation
}

\author{
Zhou, Shaofeng; Huang, Shaobin; Li, Xiaohu; Angelidaki, Irini; Zhang, Yifeng
}

Published in:

Chemical Engineering Journal

Link to article, DOI:

10.1016/j.cej.2018.02.090

Publication date:

2018

Document Version

Peer reviewed version

Link back to DTU Orbit

Citation (APA):

Zhou, S., Huang, S., Li, X., Angelidaki, I., \& Zhang, Y. (2018). Microbial electrolytic disinfection process for highly efficient Escherichia coli inactivation. Chemical Engineering Journal, 342, 220-227.

https://doi.org/10.1016/j.cej.2018.02.090

\section{General rights}

Copyright and moral rights for the publications made accessible in the public portal are retained by the authors and/or other copyright owners and it is a condition of accessing publications that users recognise and abide by the legal requirements associated with these rights.

- Users may download and print one copy of any publication from the public portal for the purpose of private study or research.

- You may not further distribute the material or use it for any profit-making activity or commercial gain

- You may freely distribute the URL identifying the publication in the public portal 


\section{Accepted Manuscript}

Microbial electrolytic disinfection process for highly efficient Escherichia coli inactivation

Shaofeng Zhou, Shaobin Huang, Xiaohu Li, Irini Angelidaki, Yifeng Zhang

PII:

S1385-8947(18)30303-6

DOI:

https://doi.org/10.1016/j.cej.2018.02.090

Reference:

CEJ 18569

To appear in: $\quad$ Chemical Engineering Journal

Received Date: $\quad 18$ November 2017

Revised Date: $\quad 20$ January 2018

Accepted Date: $\quad 20$ February 2018

Please cite this article as: S. Zhou, S. Huang, X. Li, I. Angelidaki, Y. Zhang, Microbial electrolytic disinfection process for highly efficient Escherichia coli inactivation, Chemical Engineering Journal (2018), doi: https://doi.org/ 10.1016/j.cej.2018.02.090

This is a PDF file of an unedited manuscript that has been accepted for publication. As a service to our customers we are providing this early version of the manuscript. The manuscript will undergo copyediting, typesetting, and review of the resulting proof before it is published in its final form. Please note that during the production process errors may be discovered which could affect the content, and all legal disclaimers that apply to the journal pertain. 
Submission to Chemical Engineering Journal

Microbial electrolytic disinfection process for highly efficient Escherichia coli inactivation

Shaofeng Zhou ${ }^{1,2}$, Shaobin Huang ${ }^{* 1}$, Xiaohu $\mathrm{Li}^{2}$, Irini Angelidaki ${ }^{2}$, Yifeng Zhang $*^{2}$

1. School of Environment and Energy, South China University of Technology, Higher Education Mega Center, Guangzhou 510006, PR China ${ }^{a}$

2. Department of Environmental Engineering, Technical University of Denmark, DK-2800 Lyngby, Denmark ${ }^{\mathrm{a}}$

*Corresponding author:

Dr. Yifeng Zhang

Department of Environmental Engineering, Technical University of Denmark, Denmark

Tel: (+45) 91989992;

E-mail address: yifz@env.dtu.dk

Dr. Shaobin Huang

School of Environment and Energy, South China University of Technology, China

Tel: (+86) 13527787077;

E-mail address: chshuang@scut.edu.cn 


\section{Abstract}

Water quality deterioration caused by a wide variety of recalcitrant organics and pathogenic microorganisms has become a serious concern worldwide. Bio-electroFenton systems have been considered as cost-effective and highly efficient water treatment platform technology. While it has been extensively studied for recalcitrant organics removal, its application potential towards water disinfection (e.g., inactivation of pathogens) is still unknown. This study investigated the inactivation of Escherichia coli in a microbial electrolysis cell based bio-electro-Fenton system (renamed as microbial electrolytic-Fenton cell) with the aim to broad the application of microbial electrochemistry. Results showed that a 4-log reduction of Escherichia coli $\left(10^{7}\right.$ to hundreds $\left.\mathrm{CFU} / \mathrm{mL}\right)$ was achieved with an external applied voltage of 0.2 $\mathrm{V}, 0.3 \mathrm{mM} \mathrm{Fe} \mathrm{F}^{2+}$ and cathodic $\mathrm{pH}$ of 3.0. However, non-notable inactivation was observed in the control experiments without external voltage or $\mathrm{Fe}^{2+}$ dose. The disinfection effect was enhanced when cathode air flow rate increased from 7 to 41 $\mathrm{mL} / \mathrm{min}$ and was also in proportion to the increase of $\mathrm{Fe}^{2+}$ concentration from 0.15 to $0.45 \mathrm{mmol} / \mathrm{mL}$. Fatal cell membrane destruction by $\bullet \mathrm{OH}$ was identified as one potential mechanism for disinfection. This study successfully demonstrated the feasibility of bio-electro-Fenton process for pathogens inactivation, which offers insight for the future development of sustainable, efficient, and cost-effective biological water treatment technology.

Keywords: Disinfection; Escherichia coli; Microbial electrolysis cell; Bio-ElectroFenton reactions; Advanced oxidation process; Hydrogen peroxide 


\section{Introduction}

Water contamination by pathogenic microorganisms may cause serious diseases to human beings, which makes sanitation a priority issue worldwide in recent years [1]. The increasing pressure on calling for pure water flows (e.g., drinking water) leads to the research of more efficient and sustainable technology for biohazards inactivation. Several disinfection processes (e.g., chlorination, ozonation and photocatalysis) have been developed in the past years with extended prospects. However, most of the technologies suffer from inherent drawbacks such as cost, energy-intensive, toxic byproducts or low efficiency $[2,3]$, thus it is of importance to develop an innovative technology that could address these limitations.

Among all the chemical disinfection approaches, Fenton reaction, mainly benefiting from the powerful oxidation capability of hydroxyl radical derivatives produced from hydrogen peroxide and catalysts (e.g., iron (II)), has been proven highly effective on disinfection process $[4,5]$. This disinfectant presents disinfection efficacy in a relative wide spectrum of microbes including but not limited to bacteria, viruses and spores, by launching an attack on cell membrane, nucleic acid molecules, etc. [6]. Though promising, the technology is still facing several challenges. Firstly, $\mathrm{H}_{2} \mathrm{O}_{2}$ as the main reactant of Fenton reaction is mainly produced from complex anthraquinone oxidation process [7]. Secondly, the supply of $\mathrm{H}_{2} \mathrm{O}_{2}$ is also limited by safety risks of transportation and storage so as to be restrained in many fields.

Recently, bio-electro-Fenton systems, which integrate Fenton reaction into various bio-electro-chemical systems (BES), have been widely studied in the field of biorefractory organic wastewater treatment [8-11] due to their unique merits in costeffective and efficient in-situ $\mathrm{H}_{2} \mathrm{O}_{2}$ generation [12]. The first generation of bio- 
electro-Fenton systems is based a typical BES termed microbial fuel cell (MFC) [1315]. In this system, oxygen is reduced to $\mathrm{H}_{2} \mathrm{O}_{2}$ through a two-electron reduction pathway (eq. 1) at the surface of cathode by receiving the electrons transferred from the bacterial oxidation of organics in anode $[16,17]$. As a result, electricity is generated and the $\mathrm{H}_{2} \mathrm{O}_{2}$ produced in-situ in the cathode reacts with $\mathrm{Fe}^{2+}$ to form $\bullet \mathrm{OH}$, a very reactive compound effective for water purification (eq. 2) [9, 18]. Latterly, it was found that the treatment capacity can be boosted by supplying small amounts of electricity $(0.2-1.0 \mathrm{~V})$ to the system, due to the improved $\mathrm{H}_{2} \mathrm{O}_{2}$ production [19]. In lights of the advantages in $\mathrm{H}_{2} \mathrm{O}_{2}$ production and utilization, the bio-electro-Fenton systems have been applied to treat a broad spectrum of recalcitrant organic pollutants, including azo days, aniline, pharmaceuticals, p-nitrophenol and so on $[10,11]$. However, water disinfection which could be another important application of the bioelectro-Fenton technology has never been explored.

$$
\mathrm{O}_{2}+2 \mathrm{H}^{+}+2 \mathrm{e}^{-} \rightarrow \mathrm{H}_{2} \mathrm{O}_{2}(1)
$$

$\mathrm{H}_{2} \mathrm{O}_{2}+\mathrm{Fe}^{2+} \rightarrow \cdot \mathrm{OH}+\mathrm{Fe}^{3+}+\mathrm{OH}^{-}(2)$

Herein, an innovative application of the bio-electro-Fenton system for the inactivation of pathogenic microorganisms in water ( $E$. coli as a model), named microbial electrolytic disinfection (MED) process, was proposed and investigated. In this process, the bacteria in the anode of MFC assisted with small input voltage (0.1$0.4 \mathrm{~V}$ ) will first oxidize organics and transfer the electrons to the cathode for $\mathrm{H}_{2} \mathrm{O}_{2}$ synthesis (eq.1), which will react with $\mathrm{Fe}^{2+}$ to form $\bullet \mathrm{OH}$ (eq.2). The $\bullet \mathrm{OH}$ could oxidize organic pollutants and inactivate pathogens. To date, bio-electro-Fenton systems have never been applied for water disinfection. The objective of this work is to elucidate and demonstrate the feasibility of the MED process as simple, cost- 
effective, efficient and reliable approach for water disinfection. The performance of the system was evaluated in terms of cell inactivation effects, electron flows, and hydrogen peroxide generation/utilization. The effect of different operating parameters (e.g. cathodic aeration rate, external applied voltage and $\mathrm{Fe}^{2+}$ concentrations) on the disinfection effect was also evaluated. The outcomes are expected to offer an efficient, cost-effective and environment-friendly platform technology for water disinfection, and expand the application of microbial electrochemical system.

\section{Materials and methods}

\subsection{Reactor setup and operation}

Dual-chamber reactor with $100 \mathrm{~mL}$ total volume and $80 \mathrm{~mL}$ working volume of each chamber was used for this study (Figure 1). The anode electrode was carbon brush (5.9 $\mathrm{cm}$ in diameter, $6.9 \mathrm{~cm}$ in length, Mill-Rose, USA) on which the exoelectrogenic biofilm was first enriched in MFC mode for about one month using domestic wastewater as organic sources. An auxiliary glass bottle containing necessary nutrients solution was connected with anode chamber. Recirculation of the solution through anode was adopted to ensure efficient mass transfer and maintain the sufficient fuels for biofilm. The cathode was made of graphite plate $(4 \mathrm{~cm} \times 3.5 \mathrm{~cm} \times$ $0.4 \mathrm{~cm}$ ) and was boiled in $3 \mathrm{M} \mathrm{H}_{2} \mathrm{SO}_{4}$ for ten minutes prior to use. A cation exchange membrane (CEM) (CMI 7000, membrane international, NJ) was used to separate two chambers. An $\mathrm{Ag} / \mathrm{AgCl}$ reference electrode (+0.197 V vs SHE) was inserted into cathode chamber, close to the graphite plate (all potentials presented in this article were presented versus this electrode).

\section{Figure 1 is here}


In the biofilm enrichment stage, the anode and cathode chambers were respectively fed with domestic wastewater and $50 \mathrm{mM}$ potassium ferricyanide. The domestic wastewater was collected from primary clarifier (Lyngby Wastewater Treatment Plant, Copenhagen, Denmark) which was amended by $1 \mathrm{~g} / \mathrm{L}$ acetate prior to use. The characteristics of the wastewater were described previously [10]. After enrichment for around one month, mature anodic biofilm was formed when stable maximum voltage $(\sim 650 \mathrm{mV})$ was observed in several successive batches. Subsequently, the reactor was switched into MEC mode and the anolyte was replaced by synthetic nutrient medium including $1 \mathrm{~g} / \mathrm{L}$ acetate, $0.31 \mathrm{~g} / \mathrm{L}$ ammonia chloride, $50 \mathrm{mM}$ phosphate buffer solution (PBS), $12.5 \mathrm{~mL} / \mathrm{L}$ mineral solution and $12.5 \mathrm{~mL} / \mathrm{L}$ vitamin solution. Meanwhile, $E$. coli contaminated water samples prepared based on $50 \mathrm{mM}$ sodium sulfate was added into the cathode instead of potassium ferricyanide, so as to prevent the bacteria from cell lysis. The initial catholyte $\mathrm{pH}$ was adjusted to $3.0 \pm 0.1$ using $3 \mathrm{mM} \mathrm{H}_{2} \mathrm{SO}_{4}$ and $0.3 \mathrm{mM} \mathrm{NaOH} . \mathrm{FeSO}_{4}$ of $0.3 \mathrm{mM}$ was added into catholyte, except for the tests of different concentrations of ferrous. Constant voltage of $0.2 \mathrm{~V}$ was applied using a potentiostat (CT-4008W, Neware Battery Testing System, China). The cathode cell was continuously aerated through a $45 \mu \mathrm{m}$ filter by a peristaltic pump at a rate of 29.8 $\mathrm{mL} / \mathrm{min}$, unless otherwise stated.

\subsection{Chemicals and analysis}

Current was recorded by a battery testing system (CT-4008W, Neware Battery Testing System, China). The hydrogen peroxide concentration was measured by UVvis spectrophotometry (Spectronic 20D+, Thermo Scientific) at $400 \mathrm{~nm}$ wavelength [20]. The pH was measured by a pH meter (PHM 92 lab pH meter, Radiometer, Denmark). The current density was calculated according to the projected surface area of cathode [20]. Experiments were conducted in duplicate in a water bath at $25{ }^{\circ} \mathrm{C}$. 
Sodium sulfite solution ( $3 \mathrm{mM}$ ) of $100 \mu \mathrm{L}$ was immediately added into each sample to quench oxygen reactive species [21] before counting the colonies, and control experiments showed negligible effect of sodium sulfite on bacteria concentrations. All chemicals were analytical pure without further purification.

For scanning electron microscope (SEM) test, the E. coli containing solutions before and after treatment were centrifuged to obtain sediment pellets, which were fixed by soaking into $4 \%$ formaldehyde overnight in $4{ }^{\circ} \mathrm{C}$. Later, samples were soaked into gradient $25 \%, 50 \%, 75 \%, 95 \%$ and $100 \%$ ethanol/distilled water solutions each for 10 minutes, respectively. After that, samples were freeze-dried for two hours then powder specimens were harvested [22]. These specimens were mounted onto SEM holders and coated by nano-gold (Quorum sputter coater, UK) before observed by FEI Quanta 200 ESEM FEG (Germany).

\subsection{Inactivation tests}

The E. coli (ATCC-15597, American Type Culture Collection) was chosen as a typical pathogenic bacterium in this study. E. coli is considered responsible for human intestinal diseases or even worse illness and is the most commonly used model pathogen to indicate the biohazards of drinking water and water reuse under various official water quality standards [23]. The bacterium was first cultivated for 18 hours at $37{ }^{\circ} \mathrm{C}$ in Luria-Bertani medium (LB broth: tryptone, $10 \mathrm{~g} / \mathrm{L}, \mathrm{NaCl}, 10 \mathrm{~g} / \mathrm{L}$, yeast abstract, $5 \mathrm{~g} / \mathrm{L}, \mathrm{pH}$ 7.4). Subsequently, the culture was centrifuged at $6000 \mathrm{rpm}$ for 10 minutes to harvest the bacteria which were resuspended in $50 \mathrm{mM} \mathrm{Na}_{2} \mathrm{SO}_{4}$. This step was repeated three times to achieve bacterial suspension without any nutrients and metabolites from the cells [24]. E. coli suspension was stocked in $4{ }^{\circ} \mathrm{C}$ for further use. Before each experiment, E. coli from stock solution was first cultivated for 24 hours 
at $37{ }^{\circ} \mathrm{C}$ and then counted on LB-agar plates (LB broth $+18 \mathrm{~g} / \mathrm{L}$ agar) to maintain an initial bacteria density (at $\mathrm{t}=0$ minute) at around $10^{7} \mathrm{CFU} / \mathrm{mL}$.

The experiments were conducted to challenge the survival of $E$. coli in our system under different operating conditions including varied voltage supply, aeration rates and ferrous iron dosages. In the first step, the effects of external voltages ( 0 to $0.4 \mathrm{~V})$ on $E$. coli inactivation were investigated. Secondly, the disinfection efficiency was studied by increasing cathode aeration rates from 0 to $80 \mathrm{~mL} / \mathrm{min}$. Lastly, ferrous iron concentration of $0,0.15,0.30$, and $0.45 \mathrm{mg} / \mathrm{L}$ were tested. The aeration rate and external voltage were kept at respective optimal conditions for the different ferrous iron concentrations test. $\mathrm{pH}$ was adjusted to 3.0 before each test. Samples were taken out of reactor every 10 minutes and diluted immediately. Several ten-fold dilutions were inoculated on plates in triplicate. Colony forming units were counted for enumeration after incubation at $37^{\circ} \mathrm{C}$ for 24 hours. All experiments were conducted in duplicate.

\section{Results and discussions}

\subsection{E. coli inactivation in MEDC system}

The feasibility of the bio-electro-Fenton for water disinfection was investigated and the results are shown in Figure 2. With cathode aeration of $29.8 \mathrm{~mL} / \mathrm{min}, \mathrm{Fe}^{2+}$ dose of $0.3 \mathrm{mM}$ and external voltage of $0.2 \mathrm{~V}$, the concentration of E. coli dramatically decreased from $10^{7} \mathrm{CFU} / \mathrm{mL}$ to less than $1000 \mathrm{CFU} / \mathrm{mL}$ after 1 hour operation without any lag phase, resulting in a 4-log reduction of E. coli (Figure 2a). The viability loss of $E$. coli exhibited pseudo-first-order kinetic in the first 20 minutes and thereafter a much slower rate of disinfection was observed. Similar results were reported in the study on inactivation of MS2 coliphage by Fenton reaction [21]. The rapid inactivation phase was probably due to the $\bullet \mathrm{OH}$ generated by $\mathrm{Fe}^{2+}$ and $\mathrm{H}_{2} \mathrm{O}_{2}$ 
while the reduction of $\mathrm{Fe}^{3+}$ to $\mathrm{Fe}^{2+}$ contributed the later 40 minutes inactivation process [21]. Comparatively, the sterilization was not notable in the absence of aeration, $\mathrm{Fe}^{2+}$ dose or external voltage in control experiments (Figure 2). Notably, a slight increase in the E.coli concentration (the bacteria might slightly grow after inoculum) was even witnessed in an open circuit control test without aeration or $\mathrm{Fe}^{2+}$ dose, indicating the importance of Fenton reaction to the pathogen inactivation. The results also indicate that low $\mathrm{pH}$ at 3 had no significant disinfection effect on $E$. coli. It was in agreement with previous studies in which pathogenic E. coli strains could be resistance to the lethal effects of very low $\mathrm{pH}$ [25] Some $E$. coli strains could even survive for several hours at $\mathrm{pH} 2.0$ [26-28]. The bacterial inactivation could be due to the Fenton reaction where hydroxyl radicals $(\bullet \mathrm{OH})$ was generated predominately under acidic condition and a series of subsequent chain reactions were triggered by $\mathrm{Fe}^{2+}$ dose (Table S1, Supplementary data). Beside $\bullet \mathrm{OH}$, other derived reactive oxidant species like $\cdot \mathrm{HO}_{2}$ and $\mathrm{Fe}$ (IV) might be also responsible for pathogens inactivation [29]. The $\mathrm{Fe}^{3+}$ did not have disinfectant effect over $E$. coli at low dosages $(5 \mathrm{mg} / \mathrm{L}$, corresponding to $0.089 \mathrm{mmol} / \mathrm{L}$ ), but $0.87 \log$ of $E$. coli was killed when $50 \mathrm{mg} / \mathrm{L}$ $\mathrm{Fe}^{3+}$ was added [23]. The effect level of $\mathrm{Fe}^{3+}$ was much higher than what was added in this study. Thus, the disinfection observed in this study was not due to the effect of $\mathrm{Fe}^{3+} . \mathrm{Fe}(\mathrm{II}), \mathrm{Fe}(\mathrm{III})$, and $\mathrm{Fe}(\mathrm{IV})$ recycled in solution so that radical oxidative species could be persistently generated (reactions are shown in supplementary data) [21]. Under such conditions, the iron sludge precipitation was avoided during the reaction since the $\mathrm{pH}$ value was lower than 4.0 which was required for ferrous iron sludge.

\section{Figure 2 is here}

The initial $\mathrm{pH} 3.0$ was chosen to avoid ferrous precipitation by being oxidized into ferric iron at higher $\mathrm{pH}$ values, as well as preventing cell apoptosis at extremely low 
$\mathrm{pH}(\mathrm{pH} \leq 3.0)$. Besides, lower $\mathrm{pH}$ could provide sufficient protons for hydrogen peroxide synthesis (eq. 1) through two-electron pathway [30]. It was observed that $\mathrm{pH}$ increased with time during inactivation process in the cathode (Figure $2 \mathrm{~b}$ ). The $\mathrm{pH}$ values in control tests (no voltage, no aeration or $\mathrm{Fe}^{2+}$ addition) leveled out on a relative stationary state of 3.0. However, over the reaction time, an alkali increasing process was observed when $\mathrm{Fe}^{2+}$ was not added. The fluctuant $\mathrm{pH}$ might be partly attributed to $\mathrm{H}^{+}$immigration from bacterial metabolism in anode chamber to the cathode via PEM. In terms of hydrogen peroxide generation, it could be accumulated without of $\mathrm{Fe}^{2+}$ but it seemed not to contribute to disinfection (Figure 2a) as only approximate $3.5 \mathrm{mg} / \mathrm{L} \mathrm{H}_{2} \mathrm{O}_{2}$ was detected. It was still far below the level needed for disinfection [24]. Therefore it was concluded that the radical oxidative species (e.g., - $\mathrm{OH})$ were the active compounds inactivating $E$. coli, rather than other factors.

\subsection{The effect of external voltages}

The external applied voltages which determined the cathode potential of the MED system may strongly influence the performance of $E$. coli inactivation. The effect of external applied voltage on the inactivation was investigated and the results are shown in Figure 3. Antibacterial effect was not positively correlated with the applied external voltages. At $0.2 \mathrm{~V}$ applied voltage, 3.5-log bacteria were killed, which was higher than that at 0.1 (2.5-log reduction of E. coli) and $0.4 \mathrm{~V}$ (2.0-log reduction) (Figure 3a). By contrast, only a slight decrease $(0.79 \log )$ in E. coli concentration was observed in control experiment (without voltage input), which might be due to the natural death at limited nutrients condition in the cathode.

\section{Figure 3 is here}

The decrease of inactivation effect at 0.1 and $0.4 \mathrm{~V}$ might be attributed to the 
following two aspects. Firstly, disinfection in the MED system was highly relied on Fenton reaction. As ferrous iron concentration was fixed in this test, this phenomenon might be explained by the different hydrogen peroxide yield under various applied voltages. A few publications have reported that $\mathrm{H}_{2} \mathrm{O}_{2}$ produced by two-electron oxygen reduction could be accumulated under cathode potential of -0.450 to $-0.650 \mathrm{~V}$ [19], which range was well corresponding to the cathode potentials in this study (Figure 3b). It was observed that the cathode potential decreased with the increasing of applied voltage. When 0.1 and $0.2 \mathrm{~V}$ was applied, the cathode potentials were stable at -0.450 and $-0.600 \mathrm{~V}$, respectively, while the potential decreased to $-650 \mathrm{~V}$ when $0.4 \mathrm{~V}$ was applied. Although some previous works also stated that a $0.5 \mathrm{~V}$ external electric pressure was better for electro-Fenton reaction [31] in terms of oxygen reduction, it was the nature of carbon electrode that the balance of $\mathrm{H}_{2} \mathrm{O}_{2}$ and $\mathrm{H}_{2} \mathrm{O}$ generation may be different with different electrode [32]. Thus, by observing the highest efficiency of $E$. coli disinfection, $0.2 \mathrm{~V}$ was considered as a proper voltage supply in the following experiments. Secondly, preliminary experiments showed that relatively higher voltage supply caused dramatic $\mathrm{pH}$ increase in the cathode (Figure S2). It may cause iron precipitation and have harmful effect on the inactivation of $E$. coli $[11]$. When the reaction time stretched to more than 4 hours, ferric hydroxide was observed suspending in cathode solution due to the increase of $\mathrm{pH}$. The ferric precipitate, which should be avoided, would badly influence the performance by attaching onto the electrode and PEM preventing movement of ions.

\subsection{The effect of cathode aeration rate}

Bioelectrochemical Fenton disinfection was carried out under different aeration rates, i.e., achieving various dissolved oxygen concentrations in catholyte. $\mathrm{O}_{2}$ is the key factor to Fenton reaction as it was the source of $\mathrm{H}_{2} \mathrm{O}_{2}$ for two-electron reduction 
(imperfect reduction) in the system. It was confirmed by the monitored cathode potential (Figure S3). As shown in Figure 4a, when aeration rate was increased, cathode potential was approaching optimal $\mathrm{H}_{2} \mathrm{O}_{2}$ generation potential (-0.6 V). Nearly 4.0- $\log$ inactivation of E. coli was achieved when the aeration rate increased to 41 $\mathrm{mL} / \mathrm{min}$. In addition, insufficient dissolved oxygen could limit mass transfer rate, since in the system, electrode material and current density (given certain voltage) were fixed, the initial oxygen attachment on electrode surface could be main limiting factor for $\mathrm{H}_{2} \mathrm{O}_{2}$ synthesis. It was evidenced that the stronger cathode aeration, the higher current density $(0.2 \mathrm{~V}$, Figure $4 \mathrm{~b})$. On the one hand, the higher aeration (within a certain range), the higher $\mathrm{H}_{2} \mathrm{O}_{2}$ production would be achieved [11]. On the other hand, $\mathrm{Fe}^{2+}$ oxidation would occur during aeration which would disorder the $\mathrm{Fe}^{3+} / \mathrm{Fe}^{2+}$ redox cycle. Compared to $\mathrm{H}_{2} \mathrm{O}_{2}$ synthesis, the rate of $\mathrm{Fe}^{2+}$ oxidation could be much lower, and thus, the higher aeration rate can finally enhance the inactivation efficiency. It was also in agreement with previous bio-electro-Fenton studies [33]. However, when the air flow rate was increasing to $41 \mathrm{~mL} / \mathrm{min}$, no further increase in the current density was observed, indicating oxygen saturated in cathode solution, in other words, the amounts of oxygen that approached electrode did not further increased.

\section{Figure 4 is here}

\subsection{Effect of iron addition on the disinfection efficiency}

In order to minimize the reaction time and improve the inactivation effect, several tests with varied dosages of ferrous ions were conducted. The disinfection efficacy was generally strengthened with increasing of ferrous ions dosage (Figure 5). When the ferrous iron concentration increased from 0.15 to $0.45 \mathrm{mmol}\left(\mathrm{Fe}^{2+}\right) / \mathrm{L}$, E. coli inactivation was enhanced by $30 \%$ in one hour. The $\mathrm{H}_{2} \mathrm{O}_{2}$ accumulation curve indicated that the higher $\mathrm{Fe}^{2+}$ concentration, the higher utilization of $\mathrm{H}_{2} \mathrm{O}_{2}$ it would be, 
because both chemicals are responsible for hydroxyl radical generation (Table S1). This change well reflected on the inactivation performance of our system. Without $\mathrm{Fe}^{2+}$ addition, $\mathrm{H}_{2} \mathrm{O}_{2}$ could be continuously accumulated following an approximate linearly rise up to nearly $3.5 \mathrm{mg} / \mathrm{L}$ in one hour, but little bacteria were inactivated. This control experiment again confirmed that Fenton reaction was responsible for the high performance of disinfection process.

\section{Figure 5 is here}

On the other hand, $\bullet \mathrm{OH}$ generation is not the unique pathway for ferrous consumption. In this process, $\mathrm{Fe}^{2+}$ reacted as a catalyst rather than a consuming reactant so that it could be regenerated in the Fenton chain reaction hence it could remain constant in solution. Due to the continuous aeration $(29.8 \mathrm{~mL} / \mathrm{min})$, an oversaturation of dissolved oxygen $(9.18 \pm 0.04 \mathrm{mg} / \mathrm{L})$ was reached. Thus, a large proportion of $\mathrm{Fe}^{2+}$ was depleted by oxidation to $\mathrm{Fe}^{3+}$, breaking the balance of $\mathrm{Fe}^{2+}$ regeneration and would negatively affect the $\mathrm{Fe}^{3+} / \mathrm{Fe}^{2+}$ redox cycle [30]. It would further influence the second inactivation phase (later 40 minutes) as stated in section 3.1. On this basis, ferrous iron concentration was a limiting factor in disinfection of $E$. coli. It could be expected that the disinfection performance could be enhanced by increasing the ferrous ions dosage.

\subsection{Potential mechanisms for E. coli inactivation}

To further understand the mechanisms of E. coli inactivation in MED progress, the surface morphology of E. coli before and after disinfection was examined by SEM. As shown in Figure 6, significant changes in cellular structure were observed after water treatment. Untreated E. coli sample showed clear bacterial outline, intact and undamaged cell membranes, and even filiform veins which was mostly like twisted 
bacterial flagella. While after disinfection process, the cells were in wizened shape and had some holes on their membranes (Figure $6 \mathrm{c}$ and $6 \mathrm{~d}$ ). Similar cells deformation was also recently observed in E. coli disinfection process via Fenton reaction [34]. The holes and gaps on the membranes might be caused by the strong oxidation capacity of the hydroxyl radicals generated from Fenton reactions. Although hydroxyl radicals suffered from its short lifespan, they were considered responsible for the membrane damage on account of their strong reactivity to the lipid bilayer of cell membrane [35]. The damage was a kind of promotor for a series of reactions on the cytomembranes, which would excessively destroy membrane-permeability and affect the intracellular chemical environment and physiological function [3]. All these together would cause cytoplasm leaching and accelerate the death of E. coli. It has also been previously reported that the broken cell membranes might cause severe $\mathrm{K}^{+}$ leakage $[36,37]$. Potassium ions significantly contribute to bio-macromolecule formation (protein, enzymes, etc.) and maintain osmotic pressure. Furthermore, without protection of lipid bilayer, the intracellular $\mathrm{pH}$ homeostasis could be easily broken especially in the acidic cathode chamber, as stated in section 3.1. Overall, it could be concluded that the dead of E. coli might mainly be due to the outer membrane fracture and distortion under oxidative attack, and thus, they could not be re-activated after the severe structural injuries.

\section{Figure. 6 is here}

\subsection{Significance and perspectives}

Such MED process has never been reported and has several advantages over the conventional water disinfection technologies: (i) no need of externally added $\mathrm{H}_{2} \mathrm{O}_{2}$, since it is in-situ produced from oxygen reduction by the electrons harvested from 
organic pollutants in wastewater by electrochemically active microbes, (ii) lower external voltage applied (only $0.2 \mathrm{~V}$ input) compared to the previously bio-electroFenton system [31]. To further reduce the energy input, renewable electricity sources such as solar energy, wind power or wastewater-fed MFC could be used to power the process. (iii) The main disinfection mechanism was cell membrane broken and cell disorder rather than specific attack, the system may possess a broad spectrum antibacterial characteristic. (iv) Since organics are needed in the anode as substrate, the technology can fit well with the existing infrastructure of domestic wastewater treatment plant and extend the function of the plant for further water purification (recalcitrant organics removal and disinfection). In this way, organic matters are used to support the whole process rather than function as radical scavenger. The effect of bicarbonate present in the wastewater on the disinfection process should be further investigated in future work, in order to better fit the proposed technology with existing water treatment facilities. Besides, the potential applications of the technology could also be hospital wastewater purification, reuse of swimming pool water and any other places where there is a need of organic matters and pathogens removal. (v) The energy requirement of an MEC for $\mathrm{H}_{2} \mathrm{O}_{2}$ generation was calculated as $0.45 \sim 0.93 \mathrm{KWh} / \mathrm{kg}\left(\mathrm{H}_{2} \mathrm{O}_{2}\right)$, plus the polycarbonate reactor used in our pilot study and acetate dosage [20,31]. The total cost is still much lower than the price of commercial $\mathrm{H}_{2} \mathrm{O}_{2}$ purchase which equals to approx. 15 Euro/kg $\left(30 \% \mathrm{H}_{2} \mathrm{O}_{2}\right)$ (Aladdin Co., China). Chemical costs for $\mathrm{pH}$ adjustment is not avoidable for conventional Fenton process, but it can be compensated by the relatively lower cost of $\mathrm{H}_{2} \mathrm{O}_{2}$ in our system. Furthermore, our system could be further integrated with advanced Fenton process that can be operated in neutral $\mathrm{pH}$ for saving the chemical costs. Taking together, this would in short-term largely decrease the cost of water treatment and 
meet the demands of decontamination for water reuse. It was also expected in the long-term the technology to become the new benchmark for water streams treatment and disinfection industry.

Nevertheless, before being expanded in practical application, more efforts should be made so as to fulfill the great potential. Firstly, this microbial electrolytic disinfection process only effectively occurred under acidic condition as discussed above, it might to some extent make the process complex by integrating $\mathrm{pH}$ adjustment for Fenton reaction and effluent discharge. Fortunately, ferrous ions are not the only chemical to trigger $\bullet \mathrm{OH}$ generation. This system could be integrated with ultraviolet light or solar light to address the $\mathrm{pH}$ limitation and cost of $\mathrm{Fe}^{2+}$. Electrode material with larger electrochemical activated surface instead of raw pure carbon cathode should be further developed to reduce overpotential of oxygen reduction. Additionally, higher aeration rate may make the process very troublesome to scale up and speed up the alkalization process. Previous research has developed a threedimension cathode with large specific surface area which significantly increased hydrogen peroxide generation. Aeration rate could be decreased by strengthening the effective mass transfer. Secondly, in the lights of long-term stability of this system, further study is also required to track the anode microflora transition over time as system goes on. In the meantime, an exoelectrogen bacteria-predominant anode biofilm will largely shorten the start-up time. More than that, the disinfection mechanism proposed here was mainly based on the research of Staphylococcus aureus inactivation [5, 35]. The actual reaction pathways should be further identified. For instance, probe compounds (e.g., benzoic acid) or ESR analysis could be performed to differentiate and quantify the radicals. Beside SEM, more characterization methods, such as the BacLight kit fluorescent microscopic method, luciferin/luciferase test for 
determination of cellular ATP, the Bradford assay for protein measurement could be used. Thirdly, the system should be further tested with real wastewater matrix. Last but not least, the system should be moved from lab to field application by addressing the challenges during scaling up to accelerate its commercialization.

\section{Conclusions}

In this study, the microbial electrolytic-Fenton cell was proved as a promising alternative solution for water disinfection and purification. $\mathrm{H}_{2} \mathrm{O}_{2}$ was in situ produced in cathode and reacted with $\mathrm{Fe}^{2+}$ agents to trigger the Fenton reaction. System performance was affected by applied voltage, cathodic aeration rate and the mounts of $\mathrm{Fe}^{2+}$ dosage. To be more specific, batch assays revealed that applied voltage of $0.2 \mathrm{~V}$ was considered more suitable for complete inactivation. Besides, disinfection effects were in proportion to $\mathrm{Fe}^{2+}$ dosage and aeration rate, but from the economy point of view, $0.3 \mathrm{mmol}\left(\mathrm{Fe}^{2+}\right) / \mathrm{mL}$ and $29.8 \mathrm{~mL} / \mathrm{min}$ aeration was considered as optimal. $E$. coli as a model pathogen in this study was largely inactivated by Fenton oxidation process after which the cells of bacteria were severely broken by hydroxyl radicals attack.

\section{Acknowledgments}

The authors would like to thank Technician Berit Wenzell (Center of Electron Nanoscopy, Technical University of Denmark) for scanning electron microscope tests and Hector Garcia for technical assistance. This study is financially supported by the Oversea Study Program of Guangzhou Elite Project (GEP), the National Natural Science Foundation of China (Grant No. U1701243 and 51378217), Research Project of Guangdong Provincial Department of Science and Technology (Grants No. 2015B020236001 and 2016B020240002), and The Danish Council for Independent 
Research (DFF-1335-00142).

\section{Conflict of interest statement}

The authors declare that there is no conflict of interest.

\section{Reference}

[1] D.A. Jadhav, A.N. Ghadge, M.M. Ghangrekar, Simultaneous organic matter removal and disinfection of wastewater with enhanced power generation in microbial fuel cell, Bioresour Technol 163 (2014) 328-334.

[2] Y. Du, Q.Y. Wu, Y. Lu, H.Y. Hu, Y. Yang, R. Liu, F. Liu, Increase of cytotoxicity during wastewater chlorination: Impact factors and surrogates, J Hazard Mater 324 (2017) 681-690.

[3] C.L. Tang, H.W. Bai, L. Liu, X.L. Zan, P. Gao, D.D. Sun, W. Yan, A green approach assembled multifunctional $\mathrm{Ag} / \mathrm{AgBr} / \mathrm{TNF}$ membrane for clean water production \& disinfection of bacteria through utilizing visible light, Applied Catalysis B-Environmental 196 (2016) 57-67.

[4] G. Vargas, R. Moreira, D. Spricigo, H.J. Jose, TREATED DOMESTIC SEWAGE: KINETICS OF Escherichia coli AND TOTAL COLIFORM INACTIVATION BY OXIDATION WITH HYDROGEN PEROXIDE, Quimica Nova 36 (2013) 252-256.

[5] M.J. Flores, R.J. Brandi, A.E. Cassano, M.D. Labas, Chemical disinfection with H2O2 - The proposal of a reaction kinetic model, Chemical Engineering Journal 198 (2012) 388-396.

[6] M.D. Labas, C.S. Zalazar, R.J. Brandi, A.E. Cassano, Reaction kinetics of bacteria disinfection employing hydrogen peroxide, Biochemical Engineering Journal 38 (2008) 78-87. 
[7] E. Brillas, I. Sires, M.A. Oturan, Electro-Fenton Process and Related Electrochemical Technologies Based on Fenton's Reaction Chemistry, Chemical Reviews 109 (2009) 6570-6631.

[8] T. Ling, B. Huang, M. Zhao, Q. Yan, W. Shen, Repeated oxidative degradation of methyl orange through bio-electro-Fenton in bioelectrochemical system (BES), Bioresource technology 203 (2016) 89-95.

[9] X.P. Zhu, B.E. Logan, Using single-chamber microbial fuel cells as renewable power sources of electro-Fenton reactors for organic pollutant treatment, Journal of Hazardous Materials 252 (2013) 198-203.

[10] X.H. Li, X.D. Jin, N.N. Zhao, I. Angelidaki, Y.F. Zhang, Novel bio-electroFenton technology for azo dye wastewater treatment using microbial reverseelectrodialysis electrolysis cell, Bioresour Technol 228 (2017) 322-329.

[11] X. Li, X. Jin, N. Zhao, I. Angelidaki, Y. Zhang, Efficient treatment of aniline containing wastewater in bipolar membrane microbial electrolysis cell-Fenton system, Water Res 119 (2017) 67-72.

[12] L. Zhuang, S. Zhou, Y. Li, T. Liu, D. Huang, In situ Fenton-enhanced cathodic reaction for sustainable increased electricity generation in microbial fuel cells, J. Power Sources 195 (2010) 1379-1382.

[13] Y. Li, A. Lu, H. Ding, X. Wang, C. Wang, C. Zeng, Y. Yan, Microbial fuel cells using natural pyrrhotite as the cathodic heterogeneous Fenton catalyst towards the degradation of biorefractory organics in landfill leachate, Electrochemistry Communications 12 (2010) 944-947.

[14] X.W. Liu, X.F. Sun, D.B. Li, W.W. Li, Y.X. Huang, G.P. Sheng, H.Q. Yu, Anodic Fenton process assisted by a microbial fuel cell for enhanced degradation of organic pollutants, Water Res 46 (2012) 4371-4378. 
[15] L. Zhuang, S. Zhou, Y. Yuan, M. Liu, Y. Wang, A novel bioelectro-Fenton system for coupling anodic COD removal with cathodic dye degradation, Chemical Engineering Journal 163 (2010) 160-163.

[16] S. Freguia, S. Tsujimura, K. Kano, Electron transfer pathways in microbial oxygen biocathodes, Electrochim. Acta 55 (2010) 813-818.

[17] J.-y. Chen, N. Li, L. Zhao, Three-dimensional electrode microbial fuel cell for hydrogen peroxide synthesis coupled to wastewater treatment, J. Power Sources 254 (2014) 316-322.

[18] N. Xu, Y.Y. Zhang, H.C. Tao, S.G. Zhou, Y.Q. Zeng, Bio-electro-Fenton system for enhanced estrogens degradation, Bioresour Technol 138 (2013) 136-140.

[19] J.-Y. Chen, L. Zhao, N. Li, H. Liu, A microbial fuel cell with the threedimensional electrode applied an external voltage for synthesis of hydrogen peroxide from organic matter, J. Power Sources 287 (2015) 291-296.

[20] X.H. Li, I. Angelidaki, Y.F. Zhang, Salinity-gradient energy driven microbial electrosynthesis of hydrogen peroxide, Journal of Power Sources 341 (2017) 357-365. [21] J.Y. Kim, C. Lee, D.L. Sedlak, J. Yoon, K.L. Nelson, Inactivation of MS2 coliphage by Fenton's reagent, Water research 44 (2010) 2647-2653.

[22] Y.F. Zhang, B.K. Min, L.P. Huang, I. Angelidaki, Generation of Electricity and Analysis of Microbial Communities in Wheat Straw Biomass-Powered Microbial Fuel Cells, Appl. Environ. Microbiol. 75 (2009) 3389-3395.

[23] J. Rodriguez-Chueca, A. Mediano, M.P. Ormad, R. Mosteo, J.L. Ovelleiro, Disinfection of wastewater effluents with the Fenton-like process induced by electromagnetic fields, Water research 60 (2014) 250-258. 
[24] P.Z. Sun, C. Tyree, C.H. Huang, Inactivation of Escherichia coli, Bacteriophage MS2, and Bacillus Spores under UV/H2O2 and UV/Peroxydisulfate Advanced Disinfection Conditions, Environ. Sci. Technol. 50 (2016) 4448-4458.

[25] G.J. Leyer, L.L. Wang, E.A. Johnson, Acid adaptation of Escherichia coli O157:H7 increases survival in acidic foods, Appl. Environ. Microbiol. 61 (1995) $3752-3755$.

[26] J. Lin, I.S. Lee, J. Frey, J.L. Slonczewski, J.W. Foster, Comparative analysis of extreme acid survival in Salmonella typhimurium, Shigella flexneri, and Escherichia coli, Journal of bacteriology 177 (1995) 4097-4104.

[27] J. Lin, M.P. Smith, K.C. Chapin, H.S. Baik, G.N. Bennett, J.W. Foster, Mechanisms of acid resistance in enterohemorrhagic Escherichia coli, Appl. Environ. Microbiol. 62 (1996) 3094-3100.

[28] K.Y. Djoko, M.D. Phan, K.M. Peters, M.J. Walker, M.A. Schembri, A.G. McEwan, Interplay between tolerance mechanisms to copper and acid stress in Escherichia coli, Proc. Natl. Acad. Sci. U. S. A. 114 (2017) 6818-6823.

[29] J.Y. Kim, C. Lee, D.C. Love, D.L. Sedlak, J. Yoon, K.L. Nelson, Inactivation of MS2 Coliphage by Ferrous Ion and Zero-Valent Iron Nanoparticles, Environmental Science \& Technology 45 (2011) 6978-6984.

[30] L. Zhang, X. Yin, S.F.Y. Li, Bio-electrochemical degradation of paracetamol in a microbial fuel cell-Fenton system, Chemical Engineering Journal 276 (2015) 185-192. [31] R.A. Rozendal, E. Leone, J. Keller, K. Rabaey, Efficient hydrogen peroxide generation from organic matter in a bioelectrochemical system, Electrochem. Commun. 11 (2009) 1752-1755. 
[32] A. Cournet, M. Berge, C. Roques, A. Bergel, M.L. Delia, Electrochemical reduction of oxygen catalyzed by Pseudomonas aeruginosa, Electrochim. Acta 55 (2010) 4902-4908.

[33] Y. Zhang, Y. Wang, I. Angelidaki, Alternate switching between microbial fuel cell and microbial electrolysis cell operation as a new method to control $\mathrm{H} 2 \mathrm{O} 2$ level in Bioelectro-Fenton system, J. Power Sources 291 (2015) 108-116.

[34] D. Ghernaout, Microorganisms’ Electrochemical Disinfection Phenomena, EC Microbiology 9.4 (2017) 160-169.

[35] Q. Zhang, R.N. Ma, Y. Tian, B. Su, K.L. Wang, S. Yu, J. Zhang, J. Fang, Sterilization Efficiency of a Novel Electrochemical Disinfectant against Staphylococcus aureus, Environ. Sci. Technol. 50 (2016) 3184-3192.

[36] Y. Hou, X. Li, Q. Zhao, G. Chen, C.L. Raston, Role of Hydroxyl Radicals and Mechanism of Escherichia coli Inactivation on $\mathrm{Ag} / \mathrm{AgBr} / \mathrm{TiO} 2$ Nanotube Array Electrode under Visible Light Irradiation, Environ. Sci. Technol. 46 (2012) 40424050.

[37] J. Ren, W.Z. Wang, L. Zhang, J. Chang, S. Hu, Photocatalytic inactivation of bacteria by photocatalyst Bi2WO6 under visible light, Catalysis Communications 10 (2009) $1940-1943$. 


\section{Figure captions}

Figure 1 Schematic illustration of disinfection in Bio-electro-Fenton System

Figure 2 Inactivation of $E$. coli (a), $\mathrm{pH}$ changes (b) and hydrogen peroxide accumulation in bio-electro-Fenton system at initial pH 3.0 (c) (initial $[$ E. coli $]=\sim$ $10^{7} \mathrm{CFU} / \mathrm{mL},\left[\mathrm{Fe}^{2+}\right]=0.3 \mathrm{mM}$, aeration rate $=29.8 \mathrm{~mL} / \mathrm{min}$, applied voltage $=0.2 \mathrm{~V}$ ) and control experiments

Figure 3 Inactivation effects of E. coli (a) and cathode potential under various applied voltage (b) (aeration rate: $29.8 \mathrm{~mL} / \mathrm{min},\left[\mathrm{Fe}^{2+}\right]=0.3 \mathrm{mM}$ )

Figure 4 Inactivation effects and $\mathrm{pH}$, fitting line indicates the positive relationship between $\mathrm{pH}$ increasing and aeration rate (a); current density under increasing cathode aeration rate (b) (applied voltage and $\mathrm{Fe}^{2+}$ dose were fixed at $0.2 \mathrm{~V}$ and $0.3 \mathrm{mM}$, respectively)

Figure 5 Disinfection effects of E. coli under different $\mathrm{Fe}^{2+}$ additions and $\mathrm{H}_{2} \mathrm{O}_{2}$ accumulation after 60 minutes treatment (external applied voltage: $0.2 \mathrm{~V}$, aeration rate: $29.8 \mathrm{~mL} / \mathrm{min}$ )

Figure 6 SEM images of E. coli $(\mathrm{a}, \mathrm{b})$ untreated, (c, d) after bioelectro-Fenton treatment for $60 \mathrm{~min}$ (Arrows indicated that the collapses in cellular structure) 


\section{Figures}

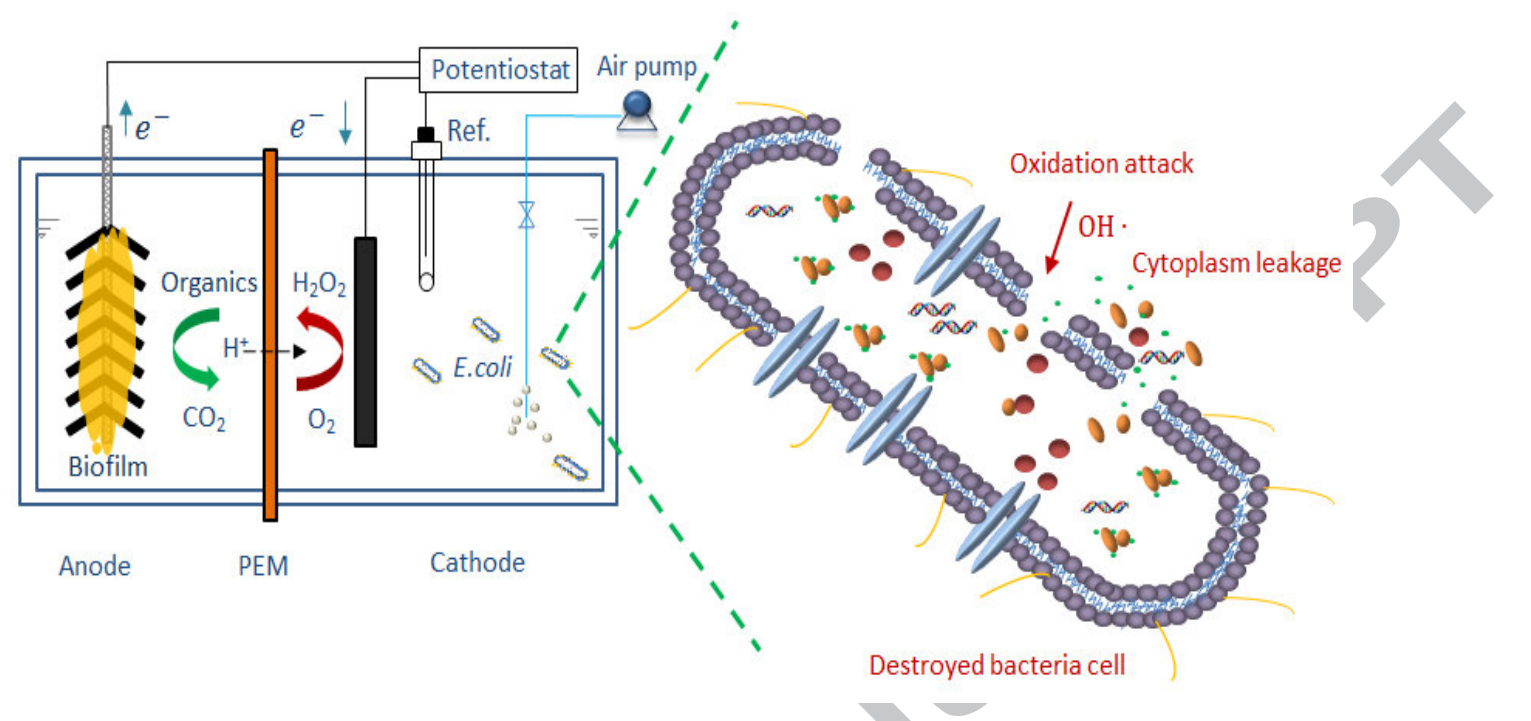

Figure 1 



Figure 2 

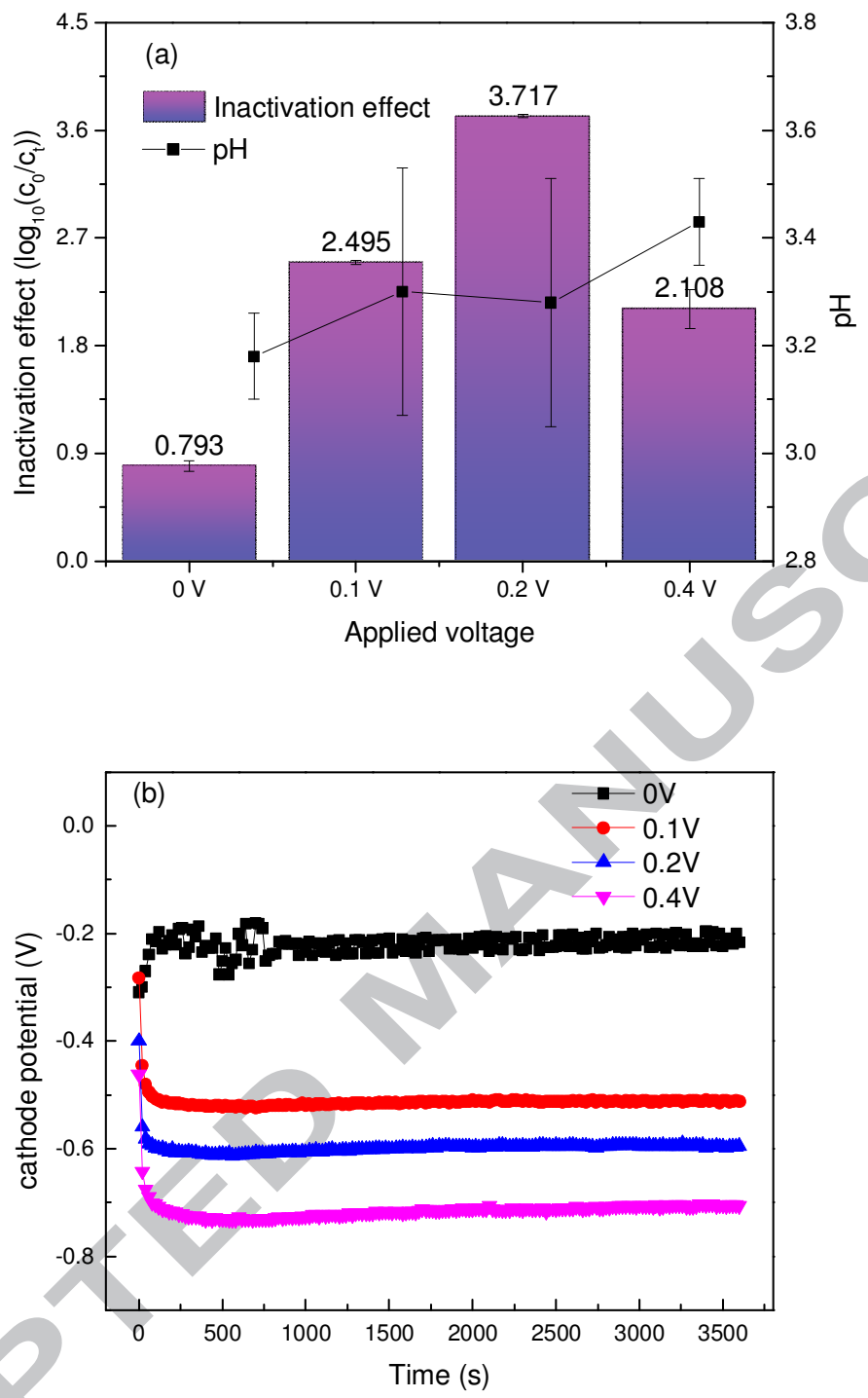

Figure 3 

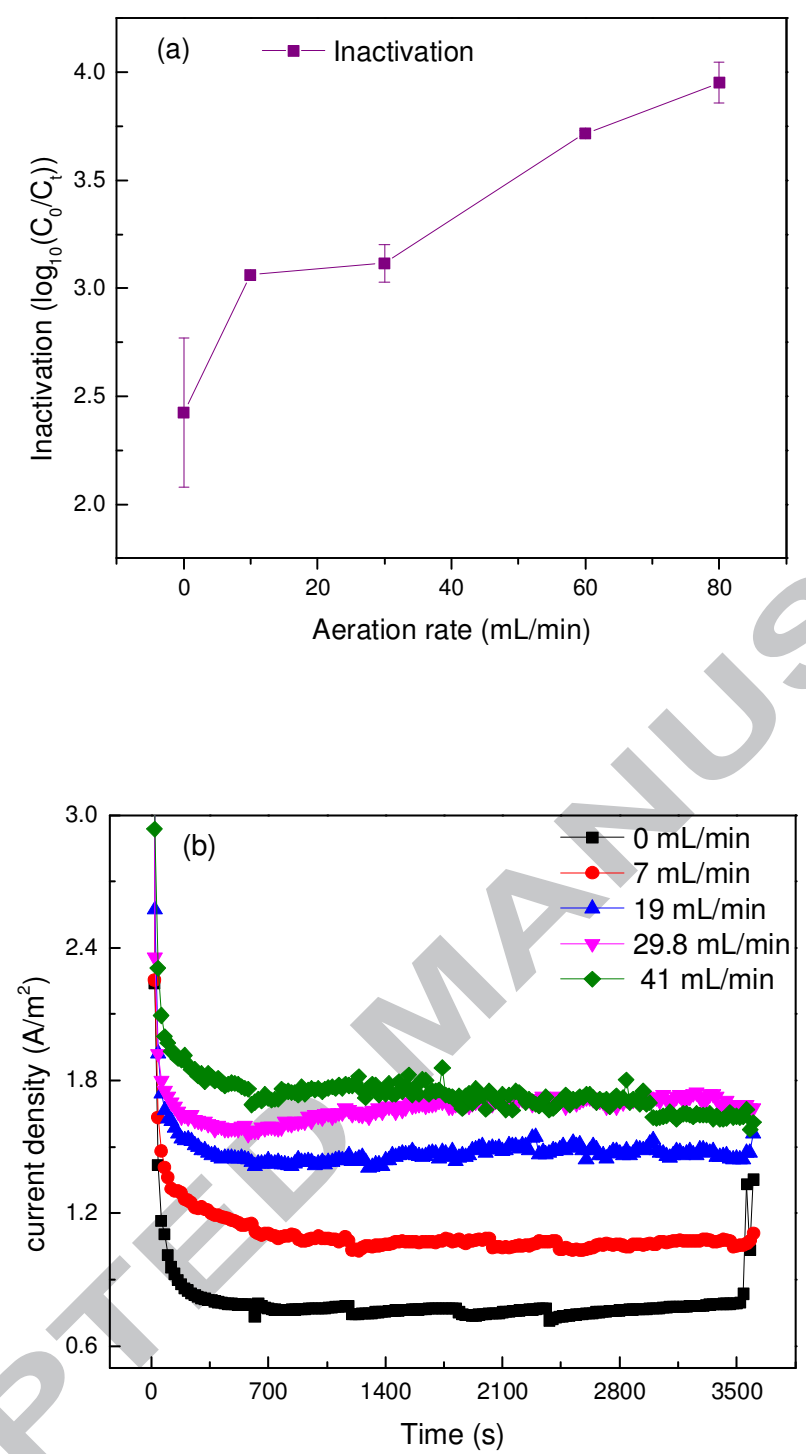

Figure 4 


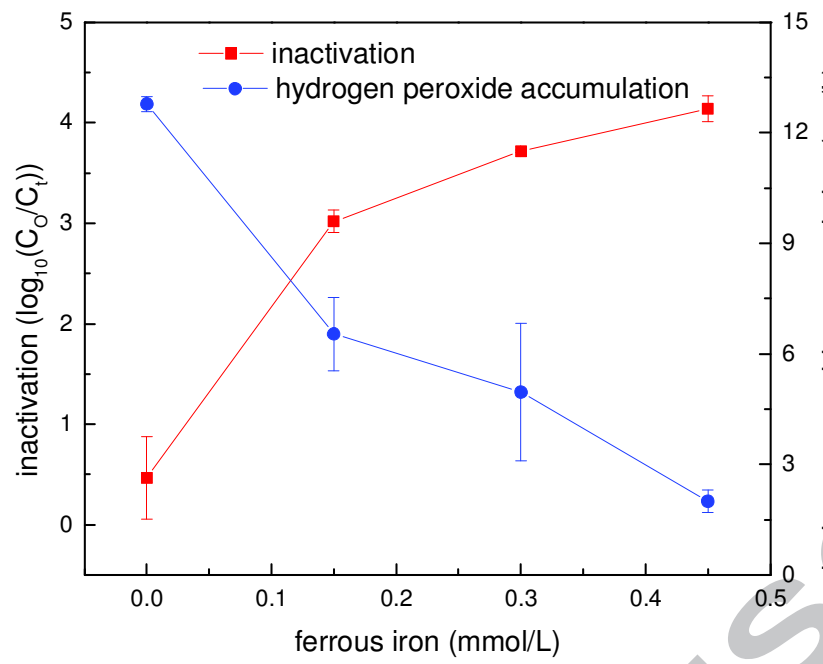

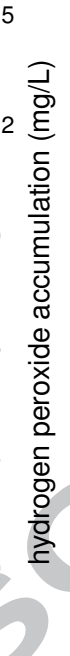

Figure 5 


\section{ACCEPTED MANUSCRIPT}


Figure 6 


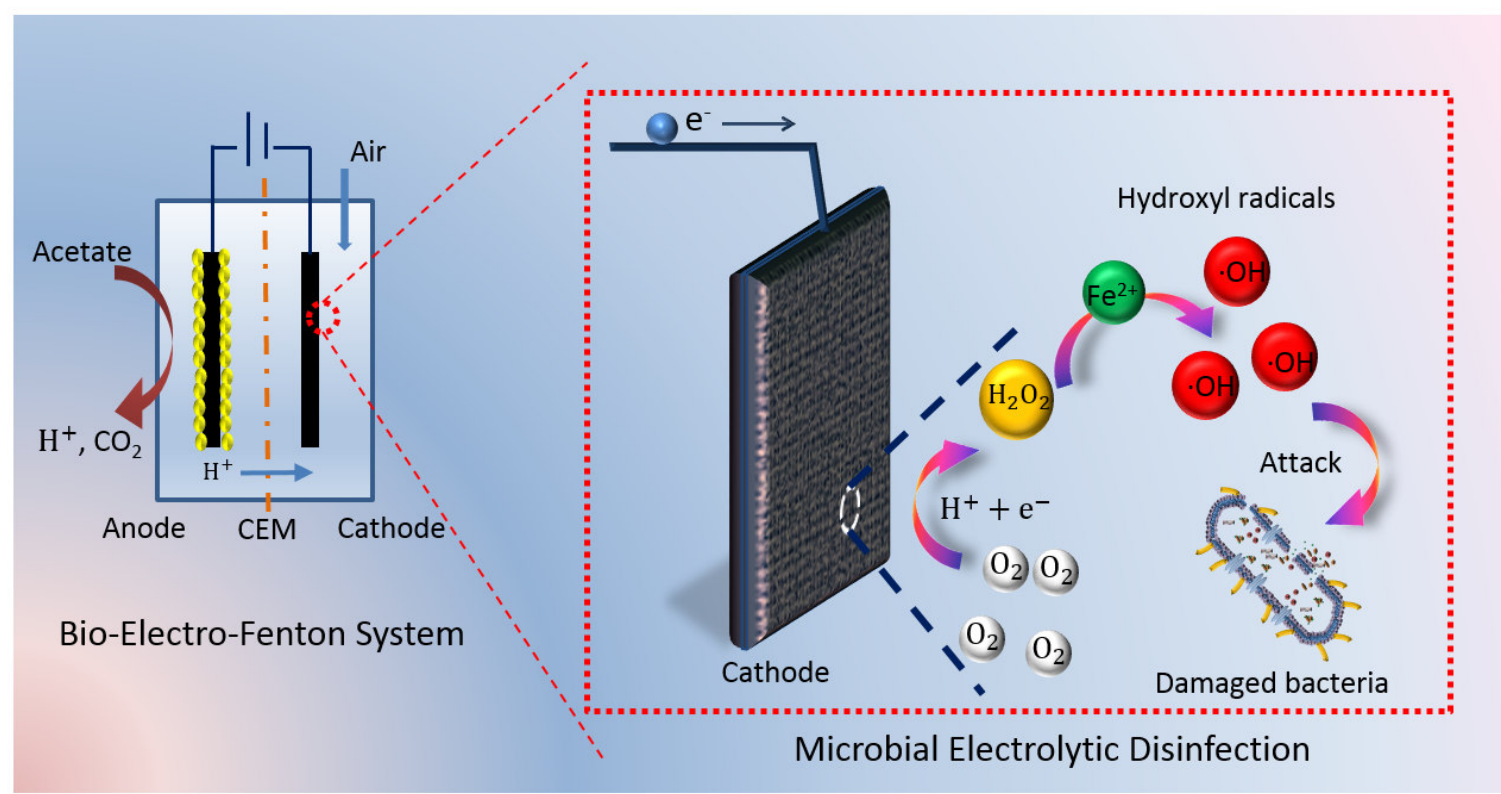

Table of Contents Art 


\section{Highlights}

- An innovative microbial electrolytic disinfection process for water purification.

- $\mathrm{H}_{2} \mathrm{O}_{2}$ was in situ synthesized in cathode to trigger Fenton reaction.

- Identified key factors affecting the $E$. coli inactivation in the system.

- Cell membrane damage as potential mechanism of $E$. coli inactivation. 